\title{
Multifunctional Microtubule-Associated Proteins in Plants
}

\author{
Jana Krtková ${ }^{1,2 *}$, Martina Benáková ${ }^{2,3}$ and Kateřina Schwarzerová ${ }^{2}$ \\ ${ }^{1}$ Department of Biology, University of Washington, Seattle, WA, USA, ${ }^{2}$ Katerina Schwarzerová Lab, Department of \\ Experimental Plant Biology, Faculty of Science, Charles University in Prague, Prague, Czech Republic, ${ }^{3}$ Department of \\ Biology, Faculty of Science, University of Hradec Králové, Rokitanského, Czech Republic
}

Microtubules (MTs) are involved in key processes in plant cells, including cell division, growth and development. MT-interacting proteins modulate MT dynamics and organization, mediating functional and structural interaction of MTs with other cell structures. In addition to conventional microtubule-associated proteins (MAPs) in plants, there are many other MT-binding proteins whose primary function is not related to the regulation of MTs. This review focuses on enzymes, chaperones, or proteins primarily involved in other processes that also bind to MTs. The MT-binding activity of these multifunctional MAPs is often performed only under specific environmental or physiological conditions, or they bind to MTs only as components of a larger MT-binding

OPEN ACCESS

Edited by:

Christopher J. Staiger,

Purdue University, USA

Reviewed by:

Chris Ambrose,

University of Saskatchewant, Canada Andrei Smertenko,

Washington State University, USA

*Correspondence: Jana Krtková akcni.krtecek@post.cz; krtkova@uw.edu

Specialty section:

This article was submitted to

Plant Cell Biology,

a section of the journal

Frontiers in Plant Science

Received: 23 January 2016

Accepted: 24 March 2016

Published: 21 April 2016

Citation:

Krtková J, Benáková M and Schwarzerová K (2016) Multifunctional Microtubule-Associated Proteins in

Plants. Front. Plant Sci. 7:474. doi: 10.3389/fpls.2016.00474 protein complex. The involvement of multifunctional MAPs in these interactions may underlie physiological and morphogenetic events, e.g., under specific environmental or developmental conditions. Uncovering MT-binding activity of these proteins, although challenging, may contribute to understanding of the novel functions of the MT cytoskeleton in plant biological processes.

Keywords: multifunctional MAP, MAP, microtubules, tubulin, plants

\section{MAPS AND THEIR ROLE IN PLANT CELLS}

Traditional microtubule-associated proteins (MAPs) are typically conserved in eukaryotes. However, plants possess a set of MAPs specific to plant morphology and physiology (Gardiner, 2013). A fundamental feature of MAPs is their interaction with MTs through a MT-binding domain that is manifested in MT organization, dynamics or cellular transport, which influences plant morphogenesis. The localization of MAPs in the cell is well described mainly because of their close association with MT structures. Consequently, MAPs are direct MT-interactors and their function is dependent on their MT-binding activity (Buschmann and Lloyd, 2008). MAPs are motor proteins that utilize MTs as tracks to transport cargo such as kinesins. Structural MAPs or severing proteins such as MAP65 and katanin bind, bundle or cleave MTs, and therefore, are involved in MT organization. MT dynamics, on the other hand, is influenced by MT +tip associated proteins (+TIPs), such as, e.g., CLASP, EB1, etc., through their binding

Abbreviations: CCT, cytosolic chaperonin containing TCP-1; EF1 $\alpha$, elongation factor 1 $\alpha$; EF2, elongation factor 2; FH2, formin homology 2; GAPDH, glyceraldehyde-3-phosphate-dehydrogenase; GDA, geldanamycin; MAP, microtubuleassociated protein; MDP, microtubule destabilizing protein; MT, microtubule; PA, phosphatidic acid; PcaP, plasma membraneassociated $\mathrm{Ca}^{2+}$-binding protein; PLD, phospholipase $\delta$; PPB, preprophase band; +TIP, +tip interacting protein. 
and interactions at the +end of growing MT. Conventional MAPs have been reviewed in several outstanding reviews (for instance Lloyd and Hussey, 2001; Akhmanova and Steinmetz, 2008; Sedbrook and Kaloriti, 2008; Gardiner, 2013; Hamada, 2014; Hashimoto, 2015; Li et al., 2015) and will not be discussed here. MAPs identified in plants are listed in the Table $\mathbf{1}$.

\section{MULTIFUNCTIONAL MAPs}

Additionally to numerous MAPs, MTs probably interact with other "fine tuning" factors that are most likely required for microtubular functions as well. The function of these proteins is not primarily related to MT-binding, but they may bind to MTs only under specific conditions. The cytoskeleton is a three-dimensional dynamic structure that can be thought of as a framework for compartmentalization of cytosolic regions. Binding of proteins to this scaffold may increase the efficiency of cellular processes by bringing interacting molecules together in place and time. In this case, MTs may function as a passive structure. Additionally, metabolic enzymes such as GAPDH have been shown to modulate MT cytoskeleton (Sirover, 1999). This suggests that multiple proteins may interact with MTs to integrate signaling pathways and the reorganization of microtubules. Along with MT-binding, these proteins perform other, MTunrelated functions. For this review, we will refer to these proteins as multifunctional MAPs as a way to distinguish them from MAPs that exclusively regulate MT structure and dynamics.

It is possible that multifunctional MAPs lack a well-defined MT-binding domain, are members of larger protein complexes and, therefore, are not found using database-based sequence similarity searches for MAPs. Instead, biochemical methods are required for their detection. The existence of a large number of proteins with known MT-unrelated functions that unexpectedly interacted with MT cytoskeleton has been documented in proteomic searches for MT-interacting proteins (Chuong et al., 2004; Korolev et al., 2005; Hamada et al., 2013; Derbyshire et al., 2015). In these experiments, tens to hundreds of cytosolic proteins interacting with tubulin or MTs were identified. However, conventional MAPs represented only a minor portion of the total MT-interacting fraction. For example, Chuong et al. (2004) used tubulin-affinity chromatography to identify a set of proteins interacting with tubulin. Only $6 \%$ of proteins were predicted as known MAPs in this protein group. Similarly, liquid chromatography-tandem mass spectrometry of MAPs-enriched fraction from Arabidopsis suspension cells was used by Hamada et al. (2013) to identify hundreds of proteins. Replication, transcription and translation-associated proteins were enriched here as well (Hamada et al., 2013). Derbyshire et al. (2015) performed a MT-pull-down protein search for MT-interacting proteins exhibiting differential accumulation during tracheary element differentiation; only $3 \%$ of proteins were classified as known MAPs (Derbyshire et al., 2015).

On the other hand, the presence of the protein in MAP enriched fraction does not always indicate its direct association with MTs. For each putative multifunctional MAP, the association with MTs or tubulin indicated by biochemical isolation needs to be tested by other methods. In contrast to MAPs, investigating the role of multifunctional MAPs associated with MTs is usually challenging. Multifunctional MAPs often cannot perform their MT-related function alone; their affinity to MTs may be dependent on factors such as upstream or feedback regulations, may be phospho- or ligand-dependent or may be of short duration, e.g., as for Hsp90 (Krtkova et al., 2012). Here we review plant proteins repeatedly found to associate with MTs whose primary function is distinct from MT-binding (Table 2). If possible, we provide a short description of their physiological function in the association with MTs.

\section{ENZYMES AND CHAPERONES}

Chaperone proteins and metabolic enzymes have been repeatedly found in MT-interacting protein fractions. Earlier, these proteins were considered as sample contaminates and their MTbinding activity was neglected. Recently, their interaction with MTs has shown to be of physiological relevance. In Arabidopsis, metabolism-related proteins were predicted to form $21 \%$ of the tubulin-interacting fraction (Chuong et al., 2004). Thirteen percent of metabolism-related proteins were detected while searching for MT-interacting proteins exhibiting differential accumulation during tracheary element development (Derbyshire et al., 2015). Nevertheless, only few of these proteins were well-studied. Examples discussed here are glyceraldehyde-3-phosphate-dehydrogenase (GAPDH) (Walsh et al., 1989; Chuong et al., 2004), chaperones Hsp70 and Hsp90 (Freudenreich and Nick, 1998; Ho et al., 2009), plant chaperonin complex CCTE subunit (Nick et al., 2000) and enzyme phospholipase D $\delta$ (PLD $\delta$ ) (Gardiner et al., 2001).

\section{GAPDH}

GAPDH is a conserved glycolytic enzyme that lyses glyceraldehyde-3-phosphate to 1,3 diphosphoglycerate. GAPDH was the first glycolytic enzyme found to be associated with tubulin and with MTs during polymerization/depolymerization cycles (Kumagai and Sakai, 1983; Somers et al., 1990). It was shown to interact directly with MTs in animals (Kumagai and Sakai, 1983; Walsh et al., 1989; Volker and Knull, 1997; Tisdale et al., 2009). Further, GAPDH plays role in vesicle trafficking, MT array arrangement, DNA replication and repair, nuclear RNA export, apoptosis or stress detection in animals (for review, see Sirover, 1999). GAPDH mediates MT-binding of other MT-interactors, such as Rab2 GTPase, therefore, it physically links MTs and membrane structures involved in secretory pathways of metazoans (Tisdale, 2002; Andrade et al., 2004). RabGTPases further interact with motor proteins that modulate vesicle binding to MTs (Hammer and $\mathrm{Wu}, 2002$; Perez et al., 2002; Howard and Hyman, 2003). Thus, GAPDH represents a multifunctional MAP with the ability to recruit a multiprotein complex to MTs in metazoans (for suggested model, see Figure 1). In plants, GAPDH was found together with other metabolic and protein synthesis enzymes, as well as signaling proteins in the tubulin binding protein fraction, which were isolated from Arabidopsis suspension cultures 
TABLE 1 | List of MAPs described in plants.

\begin{tabular}{|c|c|c|c|}
\hline MAP & Characterized in & References & Notes \\
\hline \multicolumn{4}{|l|}{ MAP65 } \\
\hline MAP65-1 & Arabidopsis thaliana & $\begin{array}{l}\text { Jiang and Sonobe, 1993; Smertenko } \\
\text { et al., 2004; Van Damme et al., } 2004\end{array}$ & \\
\hline MAP65-2 & Arabidopsis thaliana & Li et al., 2009 & \\
\hline MAP65-3/PLEIADE & Arabidopsis thaliana & Muller et al., 2004 & \\
\hline MAP65-6 & & Mao et al., 2005 & \\
\hline MAP65-7 & & Theologis et al., 2000 & Found in silico in Arabidopsis \\
\hline MAP65-8 & Arabidopsis thaliana & Smertenko et al., 2008 & Does not associate with MT \\
\hline MAP65-9 & Arabidopsis thaliana & Smertenko et al., 2008 & Pollen, does not associate with MT \\
\hline \multicolumn{4}{|c|}{ MT +END BINDING PROTEINS } \\
\hline TMBP200 & Nicotiana tabacum (BY-2) & Yasuhara et al., 2002; Hamada et al., 2004 & \\
\hline AUG8 & Arabidopsis thaliana & Cao et al., 2013 & \\
\hline \multicolumn{4}{|c|}{ KINESINS AND KINESIN-LIKE PROTEINS } \\
\hline ATK5 & Arabidopsis thaliana & Ambrose et al., 2005 & Binds also to MT + ends \\
\hline $\begin{array}{l}\mathrm{KCH} 1 \text { (kinesin with calponin } \\
\text { homology 1) }\end{array}$ & $\begin{array}{l}\text { Gossypium hirsutum, Oryza } \\
\text { sativa }\end{array}$ & Preuss et al., 2004; Frey et al., 2009 & \\
\hline $\begin{array}{l}\mathrm{KCH} 2 \text { (kinesin with calponin } \\
\text { homology 2) }\end{array}$ & Gossypium hirsutum & Xu et al., 2009 & \\
\hline $\mathrm{O} 12$ & Oryza sativa & Umezu et al., 2011 & \\
\hline kinesin 13-A & Nicotiana tabacum & Wei et al., 2005 & \\
\hline KCBP/ZWICKEL & Arabidopsis thaliana & Krishnakumar and Oppenheimer, 1999 & \\
\hline KatD & Arabidopsis thaliana & Tamura et al., 1999 & \\
\hline \multicolumn{4}{|l|}{ OTHER PROTEINS } \\
\hline TANGLED 1 & Zea mays & Smith et al., 2001 & \\
\hline $\begin{array}{l}\text { p60 katanin subunit (AtKSS, } \\
\text { AtKN1) }\end{array}$ & Arabidopsis thaliana & Burk et al., 2001 & \\
\hline p80 katanin subunit & Arabidopsis thaliana & Bouquin et al., 2003 & \\
\hline RUNKEL (RUK) & Arabidopsis thaliana & Krupnova et al., 2009 & \\
\hline Spc98p & Arabidopsis thaliana & Erhardt et al., 2002 & \\
\hline BPP1 & Arabidopsis thaliana & Hamada et al., 2013 & \\
\hline NEDD1 & Arabidopsis thaliana & Zeng et al., 2009 & $\begin{array}{l}\text { Acts as an anchoring factor of } \gamma \text {-tubulin } \\
\text { complex, decorates spindle MTs preferentially } \\
\text { toward theirs minus ends }\end{array}$ \\
\hline \multicolumn{4}{|l|}{ PLANT SPECIFIC MAPS } \\
\hline MAP190 & Nicotiana tabacum (BY-2) & Igarashi et al., 2000 & \\
\hline MAP70 - 1 & Arabidopsis thaliana & Korolev et al., 2005; Pesquet et al., 2010 & \\
\hline MAP70 -2 & Arabidopsis thaliana & Korolev et al., 2005 & \\
\hline MAP70 -3 & Arabidopsis thaliana & Korolev et al., 2005 & \\
\hline MAP70 -4 & Arabidopsis thaliana & Korolev et al., 2005 & \\
\hline
\end{tabular}


TABLE 1 | Continued

\begin{tabular}{|c|c|c|c|}
\hline MAP & Characterized in & References & Notes \\
\hline MAP70 -5 & Arabidopsis thaliana & Korolev et al., 2005, 2007 & \\
\hline SPR1 & Arabidopsis thaliana & Nakajima et al., 2004; Sedbrook, 2004 & \\
\hline SB401 & Solanum berthaultii & Huang et al., 2007 & \\
\hline SBgLR & Nicotiana tabacum & Liu et al., 2013 & Potato pollen-specific protein \\
\hline MDP40 & Arabidopsis thaliana & Wang et al., 2012 & Regulator of hypocotyl cell elongation \\
\hline WVD/WDL family & Arabidopsis thaliana & Perrin et al., 2007 & \\
\hline AlR9 & Arabidopsis thaliana & Buschmann et al., 2006 & \\
\hline
\end{tabular}

TABLE 2 | List of multifunctional MAPs described in plants.

\begin{tabular}{|c|c|c|c|}
\hline MAP & Characterized in & References & Notes \\
\hline \multicolumn{4}{|l|}{ ENZYMES OR CHAPERONS } \\
\hline GAPDH & Mammalian cells & Sirover, 1999; Tisdale et al., 2009 & \\
\hline $\begin{array}{l}\text { Glycolytic enzymes: lactate-dehydrogenase, } \\
\text { pyruvate kinase, aldolase and during specific } \\
\text { conditions also for glucose-6-phosphate isomerase } \\
\text { and phosphoglycerate-kinase }\end{array}$ & & Walsh et al., 1989 & \\
\hline Hsp70 & Arabidopsis thaliana & Ho et al., 2009 & Also involved in signaling \\
\hline Hsp90 & & $\begin{array}{l}\text { Koyasu et al., 1986; Sanchez et al., 1988; Williams } \\
\text { and Nelsen, 1997; Freudenreich and Nick, 1998; } \\
\text { Petrasek et al., 1998; Pratt et al., 1999; Lange et al., } \\
\text { 2000; de Carcer et al., 2001; Harrell et al., 2002; } \\
\text { Wegele et al., 2004; Glover, 2005; Basto et al., } \\
\text { 2007; Weis et al., 2010; Krtkova et al., } 2012\end{array}$ & Also involved in signaling \\
\hline Plant chaperone CCT & Nicotiana tabacum & Nick et al., 2000 & \\
\hline $\mathrm{EF} 1 \alpha$ & Daucus carota & Durso and Cyr, 1994 & \\
\hline $\mathrm{EF}-2$ & $\begin{array}{l}\text { Arabidopsis thaliana, } \\
\text { suspension cells }\end{array}$ & Chuong et al., 2004 & \\
\hline PLD $\delta$ & Nicotiana tabacum & Gardiner et al., 2001 & Also involved in signaling \\
\hline THO2 & Nicotiana tabacum & Hamada et al., 2009 & $\begin{array}{l}\text { Putative RNA-processing } \mathrm{THO} 2 \\
\text { relative protein }\end{array}$ \\
\hline \multicolumn{4}{|c|}{ PROTEINS INTERACTING WITH OTHER CELL STRUCTURES } \\
\hline \multicolumn{4}{|l|}{ Actin Binding Proteins } \\
\hline $\mathrm{FH} 4$ & Arabidopsis thaliana & Deeks et al., 2010 & Also involved in signaling \\
\hline $\mathrm{FH} 14$ & Arabidopsis thaliana & Li et al., 2010 & aLso involved in signaling \\
\hline $\mathrm{FH} 1$ & Arabidopsis thaliana & Rosero et al., 2013 & Also involved in signaling \\
\hline ARPC2 & Nicotiana tabacum & Havelková et al., 2015 & \\
\hline \multicolumn{4}{|l|}{ Proteins Involved in Signaling } \\
\hline PCaP2 (MAP18) & Arabidopsis thaliana & Wang et al., 2007; Kato et al., 2010 & \\
\hline MDP25 (PCaP1) & Arabidopsis thaliana & Li et al., 2011 & PCAP1, MT destabilizing protein \\
\hline MIDD1 & Arabidopsis thaliana & Oda et al., 2010 & MT-end tracking protein \\
\hline
\end{tabular}

(Chuong et al., 2004). Further, GAPDH interacted with MTs in maize endosperms (Azama et al., 2003). GAPDH was found in the Arabidopsis proteomic screen for MT-binding proteins (Derbyshire et al., 2015). However, the physiological role of plant GAPDH interaction with MTs and probable role in multiprotein complex recruitment to MTs remains unknown.
In animals, numerous glycolytic and sucrose metabolism enzymes were found to bind MTs: lactate-dehydrogenase, pyruvate kinase, aldolase, glucose-6-phosphate isomerase, phosphoglycerate-kinase, sucrose synthase, sucrose-UDP glucosyltransferase (Walsh et al., 1989). In plants, enzymes of folate-dependent pathways, fatty acid metabolism, pentose 


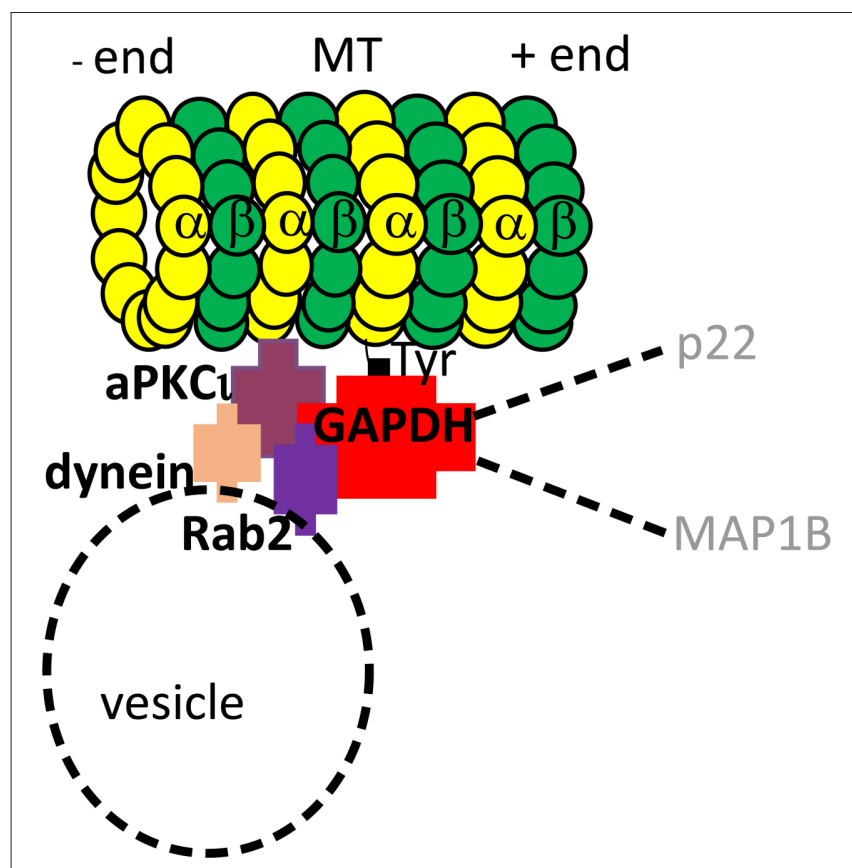

FIGURE 1 | Model of GAPDH interactions in animal cells. GAPDH, athough primarily glycolytic enzyme, is an example of a multifunctional MAP that binds to MTs and recruits a multiprotein complex to them. GAPDH binds directly to C-terminus of $\alpha$-tubulin (Kumagai and Sakai, 1983). Together with PKCı, an atypical protein kinase $\mathrm{C}$, GAPDH recruits Rab2GTPase to MTs. Additionally, Rab2GTPase and PKCı recruit dynein motor protein to the complex, which presumably links the complex to vesicle trafficking (Tisdale, 2002; Tisdale et al., 2009). A broader importance of GAPDH complex is suggested by reported binding of other proteins to the complex, such as p22 (Andrade et al., 2004) and MAP1B (Cueille et al., 2007).

phosphate pathway, phosphate metabolism, amino acid biosynthesis, the tricarboxylic acid cycle, anaerobic glycolysis, and panthothenate biosynthesis enzymes were reported in the tubulin-binding fraction in Arabidopsis (Chuong et al., 2004). The significance of these interactions remains to be elucidated, but, as indicated in animals, the interactions of metabolismrelated proteins with MTs signify a promising area of discoveries with high biological importance.

\section{Heat Shock Protein 90}

Heat shock protein 90 (Hsp90) is a highly conserved molecular chaperone essential for protein folding and stability. Along with binding various substrates in animals (Wegele et al., 2004), Hsp90 mediates switches between active and inactive states of regulatory and signaling proteins (Rutherford and Zuker, 1994). In plants, Hsp90 is involved in MAPK cascades (Takabatake et al., 2007) and R-proteins-triggered stress response (Takahashi et al., 2003; Boter et al., 2007). Hsp90 also interacts with actin and tubulin cytoskeleton (Koyasu et al., 1986; Sanchez et al., 1988; Wegele et al., 2004). Due to its numerous substrates and interacting structures including MTs, Hsp90 functions at the interface of several developmental pathways in eukaryotes (Rutherford and Lindquist, 1998).

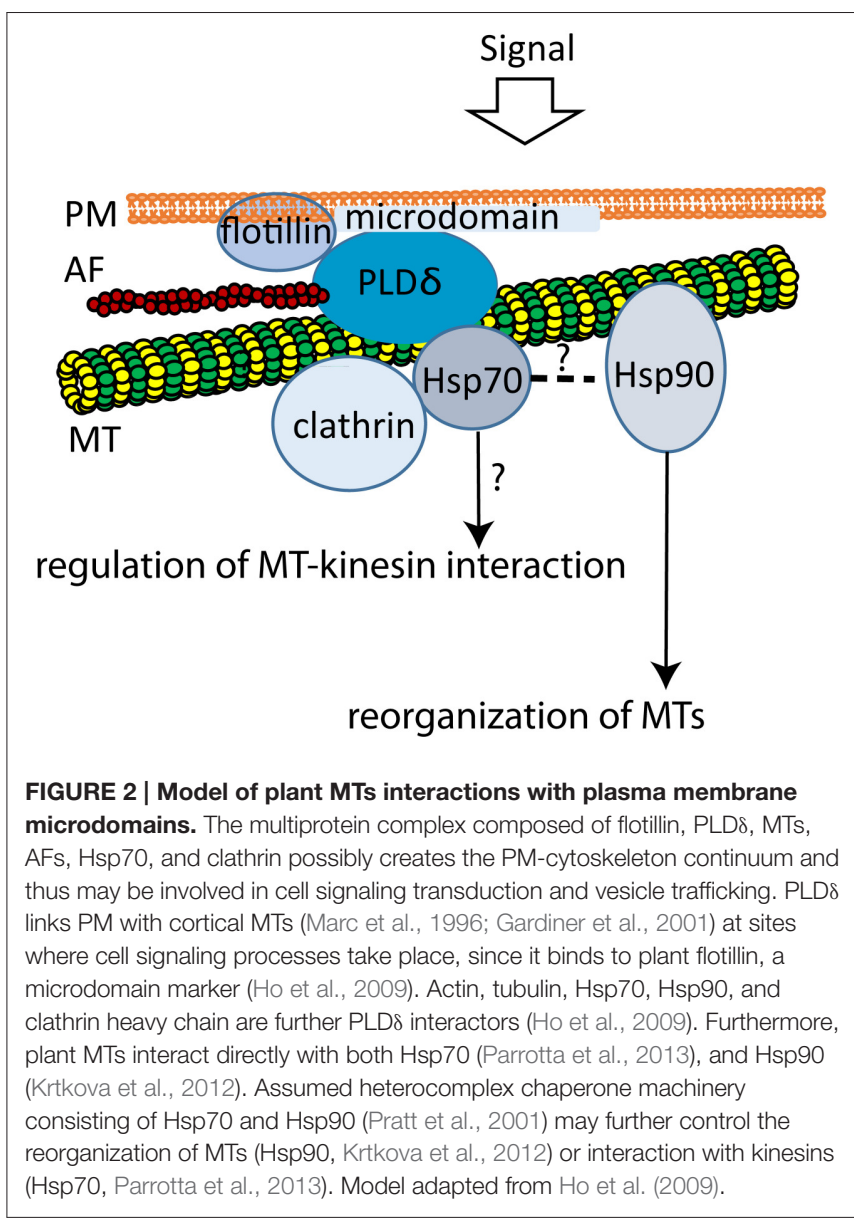

In animal cells, Hsp90 interaction with MTs appears to be complex; it interacts with tubulin dimers (Sanchez et al., 1988; Weis et al., 2010), with polymerized MTs (Fostinis et al., 1992; Williams and Nelsen, 1997) and, Hsp90 is a subunit of the heterocomplex associated with MTs during the nuclear transport of steroid hormones (Pratt et al., 1999; Harrell et al., 2002). It is found in the centrosome (Lange et al., 2000). Together with other centrosomal proteins, Hsp90 is involved in centrosome assembly and function (de Carcer et al., 2001; Glover, 2005; Basto et al., 2007).

In plants, Hsp90 is known to associate with tubulin dimers, cortical MTs and phragmoplast MTs (Freudenreich and Nick, 1998; Petrasek et al., 1998; Krtkova et al., 2012). Tobacco Hsp90 binds directly to polymerized MTs in vitro (Krtkova et al., 2012). Since the inhibition of Hsp90 severely impairs MT re-assembly after cold-induced de-polymerization, Hsp90 interaction with MTs conceivably plays a role in rapid MT re-assembly important during environmental changes or stress (Krtkova et al., 2012; Figure 2).

\section{The Cytosolic Chaperonin-Containing TCP-1 Complex}

The cytosolic chaperonin-containing TCP-1 complex (CCT), also known as the TCP1 ring complex (TRiC), plays a role in 
folding of newly synthetized actin and tubulin molecule and in organization of the MT cytoskeleton in mammalian cells (Lewis et al., 1997). In plant cells, its CCT $\varepsilon$ subunit localizes along phragmoplast MTs and cortical bundles that accompany secondary-wall thickenings (Nick et al., 2000). It is possible that CCT $\varepsilon$ is involved in the reorganization of microtubular cytoskeleton by regulating tubulin folding (Moser et al., 2000).

\section{Heat Shock Protein $\mathbf{7 0}$}

Proteins of Hsp70 family are involved in a range of cellular processes, predominantly under stress conditions, such as heat. They prevent protein aggregation, assist in protein refolding, import and translocation, signal transduction and transcriptional activation (for review, see (Zhang and Glaser, 2002; Wang et al., 2004). In the plant cortical region, Hsp70 associates with MTs and tubulin, as well as with PLD $\delta$ (Ho et al., 2009). In Chlamydomonas, the failure of the Hsp70-Hsp40 chaperone system to recognize or fold the client protein(s) results in increased MT stability and resistance to the MT-destabilizing effect of the herbicides (Silflow et al., 2011). Parrotta et al. (2013) identified a Hsp70 isoform in the pollen tube of tobacco that binds to MTs in an ATP-dependent manner. Interestingly, Hsp70 binding to MTs was also dependent on the binding of a kinesin motor p90 (Parrotta et al., 2013). This raises a possibility that Hsp70 may modulate kinesin action on MTs, a phenomenon observed also in other systems (Terada et al., 2010).

\section{PROTEIN TRANSLATION MACHINERY PROTEINS}

The interaction of cytoskeleton with polysomes was first identified in the 1970's. Since then, many data supporting the role of actin and MTs in metazoan translation machinery localization and regulation were published (for review see Kim and Coulombe, 2010). Plant transcription machinery seems to interact with the cytoskeleton as well (Muench and Park, 2006). In proteomic screens performed in plants, large groups of proteins interacting with MTs are primarily involved in RNA transcription processes. For example, Chuong et al. (2004) predicted $21 \%$ of tubulin-binding proteins assist in RNA binding and $19 \%$ in translation. Similarly, in the screen of MT-associated proteins with changed expression during tracheary element differentiation, $13 \%$ of isolated proteins were predicted to be involved in protein synthesis, and 19\% in DNA or RNA binding (Derbyshire et al., 2015). In a model proposed for plant cells, the predominant role in the transport and localization of translation machinery components is assigned to actin cytoskeleton, whereas MTs may anchor and perhaps influence the translation process (Muench and Park, 2006). Indeed, some proteins participating in the translation are repeatedly reported to associate with MTs or tubulin. Here, elongation factor $1 \alpha$ and THO2 proteins are discussed.

\section{Elongation Factor $1 \alpha$}

Elongation factor $1 \alpha(\mathrm{EF} 1 \alpha)$ is a translational factor that binds aminoacyl-tRNA and ribosomes in a GTP-dependent manner (Carneiro et al., 1999). Additionally, EF1 $\alpha$ was reported to bind and to bundle actin filaments (AFs) in animal cells (Murray et al., 1996). It is believed that F-actin-bound EF1 $\alpha$ is translationally inactive, since F-actin sequesters elongation factor $1 \alpha$ from the interaction with aminoacyl-tRNA in a $\mathrm{pH}$-dependent reaction (Liu G. et al., 1996). This suggests the role of EF1 $\alpha$ binding to $\mathrm{F}$-actin in the regulation of proteosynthesis. In addition to this, this protein was shown to sever MTs (Shiina et al., 1994). $\mathrm{EF} 1 \alpha$ is repeatedly present in plant MAP-enriched protein fractions (for example Durso and Cyr, 1994; Chuong et al., 2004; Hamada et al., 2013; Derbyshire et al., 2015). EF1 $\alpha$ influences AF dynamics (Murray et al., 1996) and MT dynamics in $\mathrm{Ca}^{2+}$ and calmodulin-dependent manner (Durso and Cyr, 1994; Moore et al., 1998). Since $\mathrm{Ca}^{2+}$ and calmodulin are key players in plant cell signaling, $\mathrm{EF} 1 \alpha$ regulation of cytoskeletal dynamics can serve as a manual transmission stick connecting the cytoskeleton and plant developmental and signaling pathways.

\section{THO2}

In animal and yeast cells, THO2 is part of the THO-TREX complex that participates in mRNA metabolism and nuclear export (Koehler and Hurt, 2007). Hamada et al. (2009) described tobacco putative $\mathrm{THO} 2$-related protein $(\mathrm{NtTHO} 2)$ as a MTassociated protein which binds directly to MTs in vitro and co-localizes with cortical MTs in vivo, indicating its role in translation targeted to specific plant cell compartments.

\section{PLASMA MEMBRANE INTERACTING PROTEINS}

In plant cells, cortical MTs underlie the plasma membrane (PM) (Dixit and Cyr, 2004). The association of cortical MTs to the PM is related to the guiding of cellulose synthase complexes (CESAs), enzyme complexes in the plasma membrane that synthesize cellulose into the extracellular space (Paredez et al., 2006). Surprisingly, only a subtle number of proteins were proven to mediate the interaction of cortical MTs with the plasma membrane. In this section, phospholipase D and developmentally-regulated plasma membrane polypeptide (DREPP) proteins are discussed. Both were first reported to participate in MT unrelated processes, however, their roles associated with MTs were revealed later. Some plant formins were reported to interact with the PM and MTs as well. Being primarily actin-associated proteins, they are discussed later in a separate chapter.

\section{Phospholipase D}

PLDs with N-terminal lipid binding domain are important signaling enzymes in plant cells (Munnik, 2001; Elias et al., 2002). Various PLD isoforms differ in their affinity to different substrates-membrane phospholipids. These are cleaved by PLDs to produce signaling molecules (Munnik, 2001; Wang, 2002).

Phospholipase $\mathrm{D} \delta$ (PLD $\delta$ ) is a central enzyme of phospholipid signaling in plants. It cleaves plasma membrane (PM) phospholipids to produce phosphatidic acid (PA) and predominantly ethanolamine and choline (for review, see Wang, 
2002). PLD $\delta$ isoform strongly associates with PM (Gardiner et al., 2001; Wang and Wang, 2001) and connects it physically with cortical MTs (Marc et al., 1996; Gardiner et al., 2001). Upon stress, e.g., $\mathrm{NaCl}$, hypoosmotic stress, xylanase or mastoparane treatment, $\mathrm{PLD} \delta$ is activated and triggers MT reorganization (Dhonukshe et al., 2003). The mechanism of PLD-triggered reorganization is likely based on the activation of PLD on the plasma membrane, which leads to the release of MTs from the membrane and MTs reorientation (Dhonukshe et al., 2003). Another potential mechanism of PLD-based MT reorganization mechanism may involve the role of PLD signaling product, PA, on MT (for review see Pleskot et al., 2014).

The importance of PLD $\delta$ in plants is confirmed by the plasma membrane and MT-binding discussed above and its interaction with actin (Ho et al., 2009). Phospholipase D $\delta$ is thus discussed hereinafter as an example of a protein potentially integrating multiple structures into a functional complex in plants.

\section{PCaP1/MDP25 and PCaP2/MAP18}

DREPP (Developmentally-Regulated Plasma membrane Polypeptide) proteins include a family of plant-specific proteins that interact with the plasma membrane (Gantet et al., 1996). Arabidopsis DREPP family contains proteins PCaP1 named also MDP25 (Ide et al., 2007; Li et al., 2011), and a divergent paralog PCaP2, first described as a Microtubule-Associated Protein 18 kDa MAP18 (Wang et al., 2007; Kato et al., 2010). PCaP1/MDP25 links calcium signaling to the regulation of cytoskeleton organization. Under normal conditions, PCaP1/MDP25 is localized to the plasma membrane. Increased calcium levels cause PCaP1/MDP25 to partially dissociate from the plasma membrane and to move into the cytosol. In the hypocotyl, cytosolic PCaP1/MDP25 binds and destabilizes cortical MTs by depolymerization and subsequently inhibits hypocotyl cell elongation ( $\mathrm{Li}$ et al., 2011). In the subapical region of pollen tubes, $\mathrm{PCaP} 1 / \mathrm{MDP} 25$ binds directly to actin cytoskeleton and severs individual actin filaments, thus negatively regulating pollen tube growth (Qin et al., 2014). PCaP2, previously reported as MT-binding MAP18 (Wang et al., 2007), is a plant-specific protein found only in Arabidopsis that is involved in intracellular signaling in growing root hairs and pollen tubes. PCaP2/MAP18 is localized in plasma membranes possibly via N-myristoylation, and destabilizes MTs (Keech et al., 2010). It is associated with specific PtdInsPs and it exhibits the capacity to bind calcium and calcium-calmodulin $\left(\mathrm{Ca}^{2+}-\mathrm{CaM}\right)$ complex (Kato et al., 2010). It is possible that association and/or dissociation of PCaP2/MAP18 with PtdInsPs via oscillation in $\mathrm{Ca}^{2+}$ cytosolic concentration regulate the signaling function of PtdIns(4,5)P2, which includes regulation of ion channels (Suh and Hille, 2008), cytoskeletal organization and membrane traffic (Meijer and Munnik, 2003; Lee et al., 2007; Kato et al., 2010).

\section{ACTIN BINDING PROTEINS AS MULTIFUNCTIONAL MAPS}

In plants, AFs are crucial for cell polarity, division, membrane trafficking and thus, growth and development. Their organization and dynamics is modulated by actin binding proteins, such as formins, Arp2/3 complex, profilin, cofilin, myosin etc. (for review see Thomas et al., 2009). An increasing list of proteins interacting with both actin and MTs in plants was reported (for review see Petrasek and Schwarzerova, 2009). The existence of proteins interacting with both AF and MT is not surprising, since actin-cytoskeletal functions are fulfilled in a close collaboration with MT cytoskeleton (Collings, 2008; Smertenko et al., 2010; Sampathkumar et al., 2011), e.g., during plant cell division, in PPB and phragmoplast (Traas et al., 1987; Mineyuki, 1999; Sano et al., 2005; Wu and Bezanilla, 2014). The following examples were reported to interact with both AFs and MTs: plant formins (Deeks et al., 2010; Li et al., 2010), a subunit of ARP2/3 protein complex ARPC2 (Havelková et al., 2015), conventional MAPs, such as kinesins (Preuss et al., 2004; Frey et al., 2009; Klotz and Nick, 2012; Schneider and Persson, 2015), plant specific MAPs, such as $190 \mathrm{kDa}$ polypeptide (Igarashi et al., 2000) and SB401 in Solanaceae (Huang et al., 2007), enzyme PLD $\delta$ (Ho et al., 2009) or protein DREPP/AtPCaP1/MDP25 (Li et al., 2011; Qin et al., 2014). Here, proteins with primary functions related to actin cytoskeleton organization that were found to interact also with MTs (formins and ARPC2) are discussed.

\section{AtFH4 and AFH14}

Formins nucleate actin and contribute to the filament growth, thus, they participate in cell polarity, morphogenesis and division (Sagot et al., 2002; Kovar and Pollard, 2004; Pruyne et al., 2004; Ingouff et al., 2005). However, some plant formins also bind directly to MTs (Deeks et al., 2010; Li et al., 2010). Formins are characterized by the presence of formin homology- 2 and formin homology-1 (FH2 and $\mathrm{FH} 1$, respectively) domains that are common in mammals and plants (Blanchoin and Staiger, 2010). Besides FH1 and FH2 domains important for actin nucleation, plant AtFH4 contains a plant-specific transmembrane domain, and a specific GOE domain that binds directly to MTs (Deeks et al., 2010). Thus, AtFH4 represents a protein that links both membranes, MTs and AFs in plant cells. Another plant formin called FORMIN14 (AFH14) appeared to bind directly either AF or MTs (Li et al., 2010). Unlike AtFH4, the FH2 domain of AFH14 is critical for both MT and AF binding and bundling. AFH14 localized to typical plant MT structures, such as preprophase band (PPB), spindles, or phragmoplast. MTs competed with AFs to bind AFH14, and the overexpression of AFH14 caused co-alignment of MTs with AFs, which perturbed the progress of cell division ( $\mathrm{Li}$ et al., 2010). Therefore, actin-binding proteins formin AtFH4 and AFH14 represent multifunctional MAPs with specialized function in mediating AF and MT crosstalk.

\section{Actin Related Protein 2/3 Complex Subunit 2}

Arp2/3 complex represents the second mechanism of $\mathrm{AF}$ nucleation. This evolutionarily conserved complex of 7 subunits (Welch et al., 1997) is functional also in plants, where it controls several aspects of plant morphogenesis (for review see Deeks and Hussey, 2005; Yanagisawa et al., 2013). Recently, 
it has been shown that actin related protein $2 / 3$ complex subunit 2 (ARPC2) of Arp2/3 complex binds directly to MTs. It is possible that the ARPC2 subunit of Arp $2 / 3$ complex mediates the interaction between MTs and AFs in plants (Havelková et al., 2015). Alternatively, Arp2/3-based interaction of MTs and AFs may contribute to mutual dynamic regulation of AFs and MTs. ARPC2 protein thus, represents another multifunctional MAP with the primary role unrelated to MT binding.

\section{MULTIFUNCTIONAL MAPs INVOLVED IN SIGNALING CROSSTALKS}

Stimuli from the outer environment are transferred into the plant cell across the rigid cellulose cell wall and lipid plasma membrane. Specific receptors on the plasma membrane may transfer stimuli by the cell wall-PM-cortical MT continuum. According to the recent studies, mediators in this physical continuum may be PLD $\delta$ and/or plant-specific formins with transmembrane domains. These proteins bind to the plasma membrane, are associated with cortical MTs and actin, and as in the case of AtFH4, possess extracellular extensinlike motifs that can anchor it to the cell wall compounds (Baluska and Hlavacka, 2005; Deeks et al., 2005, 2010; Ho et al., 2009; Cvrckova, 2013). Formins can further mediate attachment of endomembrane compartments, such as the ER or secretory vesicles, to the MT cytoskeleton (Cvrckova et al., 2015).

In addition to binding to PM phospholipids, PLD $\delta$ binds to plant flotillin homolog (Ho et al., 2009), a lipid microdomain marker (Martin et al., 2005). Lipid microdomains are PM detergent-resistant regions that are important for the assembly of multimolecular signaling complexes containing G-proteins or kinases (Martin et al., 2005; Dunkley et al., 2006; Tapken and Murphy, 2015). Therefore, PLD $\delta$ may link PM with MTs at sites where cell-signaling processes take place. However, $\mathrm{PM}$ and MTs are not PLD $\delta$ 's sole interacting structures. Factin (Kusner et al., 2003), Actin 7, Hsp70, ATPase and clathrin heavy chain (Ho et al., 2009) were reported as PLD $\delta$ interactors, too. Thus, by interacting with both cytoskeletal networks, $\mathrm{PLD} \delta$ is a possible mediator in the cell wall-PMcytoskeleton continuum. Its additional interaction with Hsp70 may contribute to the signal transduction to the cytosol (Ho et al., 2009). This interaction is probably mediated by MTs. As authors hypothesize, multiprotein complexes composed of flotillin, PLD $\delta$, MTs, AFs, Hsp70, and clathrin indirectly bound to PLD are involved in cell signaling and vesicle trafficking (Ho et al., 2009).

Hsp70 and Hsp90 cooperate in the signaling, protein folding, stabilization, and turnover by the formation of multichaperone complexes (Pratt et al., 2001, 2010). They have been reported as tubulin interactors as well (Freudenreich and Nick, 1998; Garnier et al., 1998; Petrasek et al., 1998; Parrotta et al., 2013). Since Hsp90 localizes to the cortical MTs and was isolated as the protein interacting with both PM and MTs (Krtkova et al., 2012), it is likely that the whole complex composed of Hsp90, Hsp70, MTs and actin is linked to the lipid microdomain platforms by PLD $\delta$. By this mean, the PM-cytoskeleton continuum involved in cell signaling may be established (Figure 2).

Formin interacting with both AFs and MTs (AtFH4) is possibly involved in cell signaling as well. Via its extracellular and transmembrane domain, it may transduce mechanical stimuli from the plant cell wall across PM to both cytoskeletal networks. According to the model for AtFH4 proposed in Deeks et al. (2010; see also Figure 3), mechanical stimuli transduced by forminmediating PM-cytoskeleton continuum may be preferentially manifested in actin dynamics changes. In this hypothesis, MTs represent structural scaffolds enabling $\mathrm{FH} 2$ domain of $\mathrm{AtFH} 4$ to perform its actin-nucleating function. AtFH4 also co-aligns MTs with endoplasmic reticulum, suggesting a further role of AtFH4 at the interface of actin and MT cytoskeleton (Deeks et al., 2010).

\section{PHYSIOLOGICAL DEMONSTRATION OF MULTIFUNCTIONAL MAPS-MT INTERACTION-FUTURE PROSPECTS}

Stability, dynamics and organization of MTs is modulated by their interacting proteins. MAPs, such as +TIPs (for review, see e.g., Akhmanova and Steinmetz, 2008) or other structural MAPs (Gardiner, 2013) coordinate MT reorganization events spatiotemporally, thus controlling the localization of MTs in the plant cell during specific environmental or developmental conditions. Such events underlie plant cell shape changes and plant tissue differentiation, determining survival of the plant organism through proper growth regulation.

MTs apparently require further mediating-proteins as well. These mediators may be the traditional motor or structural MAPs, but also proteins with another primary function than MT-binding. These proteins may interact with MTs in short time limits, under specific environmental conditions or interact with

? actin nucleation/
regulation of MT dynamics
FIGURE 3 I Model of plant MTs interactions with actin filaments based
on actin nucleators. Formin AtFH4 is anchored in the PM and binds to AFs,
providing a supportive scaffold for MTs attachment (Deeks et al., 2010).
ARPC2 subunit of Arp2/3 complex binds directly to MTs (Havelková et al.,
2015). The role of ARPC2-MTs interaction in the cross-linking of AFs and MTs
through Arp2/3 complex, or in the regulation of AFs and MTs dynamics,
remains to be elucidated (question mark). Model adapted from Deeks et al.
(2010).


MTs weakly or indirectly as members of MT-associated structures or complexes. Some of these proteins were discussed in this review. These spatiotemporally tightly regulated physiological functions, or secondary interactions, as well as functions of single complex subunits, are difficult to detect. Nevertheless, important progress has been made recently in identifying new multifunctional MAPs; new proteins will be added to the list in the future. Plant hormone signaling, stress and pathogen response, development of specific morphological structures and other plant specific processes represent areas for investigating new highly specific MT-associated proteins. Investigating into the functional interactions between MTs and both protein synthesis machinery and metabolism-related enzymes in plants is an exciting research area awaiting deeper exploration.

\section{REFERENCES}

Akhmanova, A., and Steinmetz, M. O. (2008). Tracking the ends: a dynamic protein network controls the fate of microtubule tips. Nat. Rev. Mol. Cell Biol. 9, 309-322. doi: 10.1038/nrm2369

Ambrose, J. C., Li, W. X., Marcus, A., Ma, H., and Cyr, R. (2005). A minus-enddirected kinesin with plus-end trackin protein activity is involved in spindle morphogenesis. Mol. Biol. Cell 16, 1584-1592. doi: 10.1091/mbc.E04-10-0935

Ambrose, J. C., Shoji, T., Kotzer, A. M., Pighin, J. A., and Wasteneys, G. O. (2007). The Arabidopsis CLASP gene encodes a microtubule-associated protein involved in cell expansion and division. Plant Cell 19, 2763-2775. doi: 10.1105/tpc.107.053777

Andrade, J., Pearce, S. T., Zhao, H., and Barros, M. (2004). Interactions among p22, glyceraldehyde-3-phosphate dehydrogenase and microtubules. Biochem. J. 384, 327-336. doi: 10.1042/BJ20040622

Asada, T., Kuriyama, R., and Shibaoka, H. (1997). TKRP125, a kinesinrelated protein involved in the centrosome-independent organization of the cytokinetic apparatus in tobacco BY-2 cells. J. Cell Sci. 110, 179-189.

Azama, K., Abe, S., Sugimoto, H., and Davis, E. (2003). Lysine-containing proteins in maize endosperm: a major contribution from cytoskeletonassociated carbohydrate-metabolizing enzymes. Planta 217, 628-638. doi: 10.1007/s00425-003-1016-5

Baluska, F., and Hlavacka, A. (2005). Plant formins come of age: something special about cross-walls. New Phytol. 168, 499-503. doi: 10.1111/j.14698137.2005.01595.x

Barroso, C., Chan, J., Allan, V., Doonan, J., Hussey, P., and Lloyd, C. (2000). Two kinesin-related proteins associated with the cold-stable cytoskeleton of carrot cells: characterization of a novel kinesin, DcKRP120-2. Plant J. 24, 859-868. doi: 10.1046/j.1365-313x.2000.00937.x

Basto, R., Gergely, F., Draviam, V. M., Ohkura, H., Liley, K., and Raff, J. W. (2007). Hsp90 is required to localise cyclin B and Msps/ch-TOG to the mitotic spindle in Drosophila and humans. J. Cell Sci. 120, 1278-1287. doi: 10.1242/jcs.000604

Blanchoin, L., and Staiger, C. J. (2010). Plant formins: diverse isoforms and unique molecular mechanism. Biochim. Biophys. Acta. Mol. Cell Res. 1803, 201-206. doi: 10.1016/j.bbamcr.2008.09.015

Boter, M., Amigues, B., Peart, J., Breuer, C., Kadota, Y., Casais, C., et al. (2007). Structural and functional analysis of SGT1 reveals that its interaction with HSP90 is required for the accumulation of $\mathrm{Rx}$, an $\mathrm{R}$ protein involved in plant immunity. Plant Cell 19, 3791-3804. doi: 10.1105/tpc.107.050427

Bouquin, T., Mattsson, O., Naested, H., Foster, R., and Mundy, J. (2003). The Arabidopsis luel mutant defines a katanin p60 ortholog involved in hormonal control of microtubule orientation during cell growth. J. Cell Sci. 116, 791-801. doi: $10.1242 /$ jcs.00274

Burk, D. H., Liu, B., Zhong, R. Q., Morrison, W. H., and Ye, Z. H. (2001). A katanin-like protein regulates normal cell wall biosynthesis and cell elongation. Plant Cell 13, 807-827. doi: 10.1105/tpc.13.4.807

\section{AUTHOR CONTRIBUTIONS}

All authors listed, have made substantial, direct and intellectual contribution to the work, and approved it for publication.

\section{ACKNOWLEDGMENTS}

We thank Dr. Alexander Paredez for supportive working environment. We highly appreciate the English language and style editing made by Kelly Hennessey. We also thank Lukáš Fischer and Jan Petrášek for stimulating discussions and continuous interest in the project. The work was supported by the project NPUI (LO1417) of Czech Ministry of Education, Youth and Sports and by the grants of Charles University GAUK to JK and MB [grant numbers $82710 / 2010$ and 990213/2012].

Buschmann, H., Chan, J., Sanchez-Pulido, L., Andrade-Navarro, M. A., Doonan, J. H., and Lloyd, C. W. (2006). Microtubule-associated AIR9 recognizes the cortical division site at preprophase and cell-plate insertion. Curr. Biol. 16, 1938-1943. doi: 10.1016/j.cub.2006.08.028

Buschmann, H., and Lloyd, C. W. (2008). Arabidopsis mutants and the network of microtubute-associated functions. Mol. Plant 1, 888-898. doi: $10.1093 / \mathrm{mp} / \mathrm{ssn} 060$

Cao, L., Wang, L., Zheng, M., Cao, H., Ding, L., Zhang, X., et al. (2013). Arabidopsis AUGMIN subunit8 is a microtubule plus-end binding protein that promotes microtubule reorientation in hypocotyls. Plant Cell 25, 2187-2201. doi: $10.1105 /$ tpc. 113.113472

Carneiro, N. P., Hughes, P. A., and Larkins, B. A. (1999). The eEFlA gene family is differentially expressed in maize endosperm. Plant Mol. Biol. 41, 801-813. doi: 10.1023/A:1006391207980

Chan, J., Calder, G. M., Doonan, J. H., and Lloyd, C. W. (2003). EB1 reveals mobile microtubule nucleation sites in Arabidopsis. Nat. Cell Biol. 5, 967-971. doi: $10.1038 / \mathrm{ncb} 1057$

Chuong, S. D. X., Good, A. G., Taylor, G. J., Freeman, M. C., Moorhead, G. B. G., and Muench, D. G. (2004). Large-scale identification of tubulinbinding proteins provides insight on subcellular trafficking, metabolic channeling, and signaling in plant cells. Mol. Cell. Proteomics 3, 970-983. doi: 10.1074/mcp.M400053-MCP200

Collings, D. A. (2008). "Crossed-wires: interactions and cross-talk between the microtubule and microfilament networks in plants," in Plant Microtubules: Development and Flexibility, 2nd Edn., Vol. 11, ed P. Nick (Berlin; Heidelberg: Springer), 47-79.

Cueille, N., Blanc, C. T., Riederer, I. M., and Riederer, B. M. (2007). Microtubuleassociated protein 1B binds glyceraldehyde-3-phosphate dehydrogenase. J. Proteome Res. 6, 2640-2647. doi: 10.1021/pr070081z

Cvrckova, F. (2013). Formins and membranes: anchoring cortical actin to the cell wall and beyond. Front. Plant Sci. 4:436. doi: 10.3389/fpls.2013.00436

Cvrckova, F., Oulehlova, D., and Zarsky, V. (2015). Formins: linking cytoskeleton and endomembranes in plant cells. Int. J. Mol. Sci. 16, 1-18. doi: 10.3390/ijms16010001

de Carcer, G., Avides, M. D., Lallena, M. J., Glover, D. M., and Gonzalez, C. (2001). Requirement of Hsp90 for centrosomal function reflects its regulation of Polo kinase stability. EMBO J. 20, 2878-2884. doi: 10.1093/emboj/20.11.2878

Deeks, M. J., Cvrckova, F., Machesky, L. M., Mikitova, V., Ketelaar, T., Zarsky, V., et al. (2005). Arabidopsis group Ie formins localize to specific cell membrane domains, interact with actin-binding proteins and cause defects in cell expansion upon aberrant expression. New Phytol. 168, 529-540. doi: 10.1111/j.1469-8137.2005.01582.x

Deeks, M. J., Fendrych, M., Smertenko, A., Bell, K. S., Oparka, K., Cvrckova, F., et al. (2010). The plant formin AtFH4 interacts with both actin and microtubules, and contains a newly identified microtubule-binding domain. J. Cell Sci. 123, 1209-1215. doi: 10.1242/jcs.065557 
Deeks, M. J., and Hussey, P. J. (2005). Arp2/3 and scar: plants move to the fore. Nat. Rev. Mol. Cell Biol. 6, 954-964. doi: 10.1038/nrm1765

Derbyshire, P., Menard, D., Green, P., Saalbach, G., Buschmann, H., Lloyd, C. W., et al. (2015). Proteomic analysis of microtubule interacting proteins over the course of xylem tracheary element formation in Arabidopsis. Plant Cell 27, 2709-2726. doi: 10.1105/tpc.15.00314

Dhonukshe, P., Laxalt, A. M., Goedhart, J., Gadella, T. W. J., and Munnik, T. (2003). Phospholipase D activation correlates with microtubule reorganization in living plant cells. Plant Cell 15, 2666-2679. doi: 10.1105/tpc.014977

Dixit, R., and Cyr, R. (2004). The cortical microtubule array: from dynamics to organization. Plant Cell 16, 2546-2552. doi: 10.1105/tpc.104.161030

Dunkley, T. P. J., Hester, S., Shadforth, I. P., Runions, J., Weimar, T., Hanton, S. L., et al. (2006). Mapping the Arabidopsis organelle proteome. Proc. Natl. Acad. Sci. U.S.A. 103, 6518-6523. doi: 10.1073/pnas.0506958103

Durso, N. A., and Cyr, R. J. (1994). A Calmodulin-sensitive interaction between microtubules and a higher-plant homolog of elongation factor-1-alpha. Plant Cell 6, 893-905. doi: 10.1105/tpc.6.6.893

Elias, M., Potocky, M., Cvrckova, F., and Zarsky, V. (2002). Molecular diversity of phospholipase D in angiosperms. BMC Genomics 3:2. doi: 10.1186/1471-21 64-3-2

Erhardt, M., Stoppin-Mellet, V., Campagne, S., Canaday, J., Mutterer, J., Fabian, T., et al. (2002). The plant Spc98p homologue colocalizes with gamma-tubulin at microtubule nucleation sites and is required for microtubule nucleation. J. Cell Sci. 115, 2423-2431.

Fostinis, Y., Theodoropoulos, P. A., Gravanis, A., and Stournaras, C. (1992). Heat-shock protein HSP90 and its association with the cytoskeleton - a morphological-study. Biochem. Cell Biol. 70, 779-786. doi: 10.1139/o92-118

Freudenreich, A., and Nick, P. (1998). Microtubular organization in tobacco cells: heat-shock protein 90 can bind to tubulin in vitro. Bot. Acta 111, 273-279. doi: 10.1111/j.1438-8677.1998.tb00708.x

Frey, N., Klotz, J., and Nick, P. (2009). Dynamic bridges a calponin-domain kinesin from rice links actin filaments and microtubules in both cycling and non-cycling cells. Plant Cell Physiol. 50, 1493-1506. doi: 10.1093/pcp/pcp094

Furutani, I., Watanabe, Y., Prieto, R., Masukawa, M., Suzuki, K., Naoi, K., et al. (2000). The SPIRAL genes are required for directional central of cell elongation in Arabidopsis thaliana. Development 127, 4443-4453.

Gaillard, J., Neumann, E., Van Damme, D., Stoppin-Mellet, V., Ebel, C., Barbier, E., et al. (2008). Two microtubule-associated proteins of Arabidopsis MAP65s promote antiparallel microtubule bundling. Mol. Biol. Cell 19, 4534-4544. doi: 10.1091/mbc.E08-04-0341

Gantet, P., Masson, F., Domergue, O., Marquismention, M., Bauw, G., Inze, D., et al. (1996). Cloning of a cDNA encoding a developmentally regulated $22 \mathrm{kDa}$ polypeptide from tobacco leaf plasma membrane. Biochem. Mol. Biol. Int. 40, 469-477. doi: 10.1080/15216549600201033

Gardiner, J. (2013). The evolution and diversification of plant microtubuleassociated proteins. Plant J. 75, 219-229. doi: 10.1111/tpj.12189

Gardiner, J. C., Harper, J. D. I., Weerakoon, N. D., Collings, D. A., Ritchie, S., Gilroy, S., et al. (2001). A $90-\mathrm{kD}$ phospholipase D from tobacco binds to microtubules and the plasma membrane. Plant Cell 13, 2143-2158. doi: 10.1105/tpc.13.9.2143

Garnier, C., Barbier, P., Gilli, R., Lopez, C., Peyrot, V., and Briand, C. (1998). Heat-shock protein 90 (hsp90) binds in vitro to tubulin dimer and inhibits microtubule formation. Biochem. Biophys. Res. Commun. 250, 414-419. doi: 10.1006/bbrc. 1998.9319

Glover, D. M. (2005). Polo kinase and progression through M phase in Drosophila: a perspective from the spindle poles. Oncogene 24, 230-237. doi: 10.1038/sj.onc. 1208279

Hamada, T. (2014). Microtubule organization and microtubule-associated proteins in plant cells. Int. Rev. Cell Mol. Biol. 312, 1-52. doi: 10.1016/B978-0-12800178-3.00001-4

Hamada, T., Igarashi, H., Itoh, T. J., Shimmen, T., and Sonobe, S. (2004). Characterization of a $200 \mathrm{kDa}$ microtubule-associated protein of tobacco BY2 cells, a member of the XMAP215/MOR1 family. Plant Cell Physiol. 45, 1233-1242. doi: 10.1093/pcp/pch145

Hamada, T., Igarashi, H., Taguchi, R., Fujiwara, M., Fukao, Y., Shimmen, T., et al. (2009). The Putative RNA-processing protein, THO2, is a microtubule-associated protein in tobacco. Plant Cell Physiol. 50, 801-811. doi: $10.1093 / \mathrm{pcp} / \mathrm{pcp} 024$
Hamada, T., Nagasaki-Takeuchi, N., Kato, T., Fujiwara, M., Sonobe, S., Fukao, Y., et al. (2013). Purification and characterization of novel microtubuleassociated proteins from arabidopsis cell suspension cultures. Plant Physiol. 163, 1804-1816. doi: 10.1104/pp.113.225607

Hammer, J. A., and Wu, X. F. S. (2002). Rabs grab motors: defining the connections between Rab GTPases and motor proteins. Curr. Opin. Cell Biol. 14, 69-75. doi: 10.1016/S0955-0674(01)00296-4

Harrell, J. M., Kurek, I., Breiman, A., Radanyi, C., Renoir, J. M., Pratt, W. B., et al. (2002). All of the protein interactions that link steroid receptor center dot hsp90 center dot immunophilin heterocomplexes to cytoplasmic dynein are common to plant and animal cells. Biochemistry 41, 5581-5587. doi: 10.1021/bi020073q

Hashimoto, T. (2015). Microtubules in plants. Arabidopsis Book 13, e0179. doi: $10.1199 /$ tab.0179

Havelková, L., Nanda, G., Martinek, J., Bellinvia, E., Sikorová, L., Šlajcherová, K., et al. (2015). Arp2/3 complex subunit ARPC2 binds to microtubules. Plant Sci. 241, 96-108. doi: 10.1016/j.plantsci.2015.10.001

Hiwatashi, Y., Sato, Y., and Doonan, J. H. (2014). Kinesins have a dual function in organizing microtubules during both tip growth and cytokinesis in Physcomitrella patens. Plant Cell 26, 1256-1266. doi: 10.1105/tpc.113.121723

Ho, A. Y. Y., Day, D. A., Brown, M. H., and Marc, J. (2009). Arabidopsis phospholipase D delta as an initiator of cytoskeleton-mediated signalling to fundamental cellular processes. Funct. Plant Biol. 36, 190-198. doi: 10.1071/FP08222

Howard, J., and Hyman, A. A. (2003). Dynamics and mechanics of the microtubule plus end. Nature 422, 753-758. doi: 10.1038/nature01600

Huang, S. L., Jin, L. F., Du, J. Z., Li, H., Zha, Q., Ou, G. S., et al. (2007). SB401, a pollen-specific protein from Solanum berthaultii, binds to and bundles microtubules and F-actin. Plant J. 51, 406-418. doi: 10.1111/j.1365313X.2007.03153.X

Ide, Y., Nagasaki, N., Tomioka, R., Suito, M., Kamiya, T., and Maeshima, M. (2007). Molecular properties of a novel, hydrophilic cation-binding protein associated with the plasma membrane. J. Exp. Bot. 58, 1173-1183. doi: 10.1093/jxb/erl284

Igarashi, H., Orii, H., Mori, H., Shimmen, T., and Sonobe, S. (2000). Isolation of a novel $190 \mathrm{kDa}$ protein from tobacco BY-2 cells: possible involvement in the interaction between actin filaments and microtubules. Plant Cell Physiol. 41, 920-931. doi: $10.1093 / \mathrm{pcp} / \mathrm{pcd} 015$

Ingouff, M., Gerald, J. N. F., Guerin, C., Robert, H., Sorensen, M. B., Van Damme, D., et al. (2005). Plant formin AtFH5 is an evolutionarily conserved actin nucleator involved in cytokinesis. Nat. Cell Biol. 7, 374-380. doi: $10.1038 /$ ncb 1238

Jiang, C. J., and Sonobe, S. (1993). Identification and preliminary characterization of A $65-\mathrm{kDA}$ higher-plant microtubule-associated protein. J. Cell Sci. 105, 891-901.

Kato, M., Nagasaki-Takeuchi, N., Ide, Y., and Maeshima, M. (2010). An Arabidopsis hydrophilic Ca-2-binding protein with a PEVK-rich domain, $\mathrm{PCaP} 2$, is associated with the plasma membrane and interacts with calmodulin and phosphatidylinositol phosphates. Plant Cell Physiol. 51, 366-379. doi: 10.1093/pcp/pcq003

Keech, O., Pesquet, E., Gutierrez, L., Ahad, A., Bellini, C., Smith, S. M., et al. (2010). Leaf senescence is accompanied by an early disruption of the microtubule network in Arabidopsis. Plant Physiol. 154, 1710-1720. doi: $10.1104 /$ pp.110.163402

Ketelaar, T., Voss, C., Dimmock, S. A., Thumm, M., and Hussey, P. J. (2004). Arabidopsis homologues of the autophagy protein Atg8 are a novel family of microtubule binding proteins. FEBS Lett. 567, 302-306. doi: 10.1016/j.febslet.2004.04.088

Kim, S., and Coulombe, P. A. (2010). OPINION Emerging role for the cytoskeleton as an organizer and regulator of translation. Nat. Rev. Mol. Cell Biol. 11, 75-81. doi: $10.1038 / \mathrm{nrm} 2818$

Kirik, V., Herrmann, U., Parupalli, C., Sedbrook, J. C., Ehrhardt, D. W., and Hulskamp, M. (2007). CLASP localizes in two discrete patterns on cortical microtubules and is required for cell morphogenesis and cell division in Arabidopsis. J. Cell Sci. 120, 4416-4425. doi: 10.1242/jcs.024950

Klotz, J., and Nick, P. (2012). A novel actin-microtubule cross-linking kinesin, NtKCH, functions in cell expansion and division. New Phytol. 193, 576-589. doi: $10.1111 / j .1469-8137.2011 .03944 . x$

Koehler, A., and Hurt, E. (2007). Exporting RNA from the nucleus to the cytoplasm. Nat. Rev. Mol. Cell Biol. 8, 761-773. doi: 10.1038/nrm2255 
Korolev, A. V., Buschmann, H., Doonan, J. H., and Lloyd, C. W. (2007). AtMAP705 , a divergent member of the MAP70 family of microtubule-associated proteins, is required for anisotropic cell growth in Arabidopsis. J. Cell Sci. 120, 2241-2247. doi: 10.1242/jcs.007393

Korolev, A. V., Chan, J., Naldrett, M. J., Doonan, J. H., and Lloyd, C. W. (2005). Identification of a novel family of $70 \mathrm{kDa}$ microtubule-associated proteins in Arabidopsis cells. Plant J. 42, 547-555. doi: 10.1111/j.1365-313X.2005.02393.x

Kovar, D. R., and Pollard, T. D. (2004). Progressing actin: sFormin as a processive elongation machine. Nat. Cell Biol. 6, 1158-1159. doi: 10.1038/ncb1204-1158

Koyasu, S., Nishida, E., Kadowaki, T., Matsuzaki, F., Iida, K., Harada, F., et al. (1986). 2 Mammalian heat-shock proteins, HSP90 and HSP100, Are Actin-Binding Proteins. Proc. Natl. Acad. Sci. U.S.A. 83, 8054-8058. doi: 10.1073/pnas.83.21.8054

Krishnakumar, S., and Oppenheimer, D. G. (1999). Extragenic suppressors of the Arabidopsis zwi-3 mutation identify new genes that function in trichome branch formation sand pollen tube growth. Development 126, 3079-3088.

Krtkova, J., Zimmermann, A., Schwarzerova, K., and Nick, P. (2012). Hsp90 binds microtubules and is involved in the reorganization of the microtubular network in angiosperms. J. Plant Physiol. 169, 1329-1339. doi: 10.1016/j.jplph.2012.06.010

Krupnova, T., Sasabe, M., Ghebreghiorghis, L., Gruber, C. W., Hamada, T., Dehmel, et al. (2009). Microtubule-associated kinase-like protein RUNKEL needed for cell plate expansion in Arabidopsis cytokinesis. Curr. Biol. 19, 518-523. doi: 10.1016/j.cub.2009.02.021

Kumagai, H., and Sakai, H. (1983). A porcine brain protein (35K-protein) which bundles microtubules and its identification as glyceraldehyde-3-phosphate dehydrogenase. J. Biochem. 93, 1259-1269.

Kusner, D. J., Barton, J. A., Qin, C. B., Wang, X. M., and Iyer, S. S. (2003). Evolutionary conservation of physical and functional interactions between phospholipase D and actin. Arch. Biochem. Biophys. 412, 231-241. doi: 10.1016/S0003-9861(03)00052-3

Lange, B. M. H., Bachi, A., Wilm, M., and Gonzalez, C. (2000). Hsp90 is a core centrosomal component and is required at different stages of the centrosome cycle in Drosophila and vertebrates. $E M B O ~ J .19,1252-1262$. doi: 10.1093/emboj/19.6.1252

Lee, Y., Kim, Y.-W., Jeon, B. W., Park, K.-Y., Suh, S. J., Seo, J., et al. (2007). Phosphatidylinositol 4,5-bisphosphate is important for stomatal opening. Plant J. 52, 803-816. doi: 10.1111/j.1365-313X.2007.03277.x

Lee, Y. R. J., and Liu, B. (2000). Identification of a phragmoplast-associated kinesin-related protein in higher plants. Curr. Biol. 10, 797-800. doi: 10.1016/S0960-9822(00)00564-9

Lewis, S. A., Tian, G. L., and Cowan, N. J. (1997). The alpha- and betatubulin folding pathways. Trends Cell Biol. 7, 479-484. doi: 10.1016/S09628924(97)01168-9

Li, H., Zeng, X., Liu, Z. Q., Meng, Q. T., Yuan, M., and Mao, T. L. (2009). Arabidopsis microtubule-associated protein AtMAP65-2 acts as a microtubule stabilizer. Plant Mol. Biol. 69, 313-324. doi: 10.1007/s11103-008-9426-1

Li, J., Wang, X., Qin, T., Zhang, Y., Liu, X., Sun, J., et al. (2011). MDP25, A novel calcium regulatory protein, mediates hypocotyl cell elongation by destabilizing cortical microtubules in Arabidopsis. Plant Cell 23, 4411-4427. doi: 10.1105/tpc.111.092684

Li, S., Sun, T., and Ren, H. (2015). The functions of the cytoskeleton and associated proteins during mitosis and cytokinesis in plant cells. Front. Plant Sci. 6:282. doi: $10.3389 /$ fpls.2015.00282

Li, Y. H., Shen, Y. A., Cai, C., Zhong, C. C., Zhu, L., Yuan, M., et al. (2010). The type II Arabidopsis formin 14 interacts with microtubules and microfilaments to regulate cell division. Plant Cell 22, 2710-2726. doi: 10.1105/tpc.110.075507

Liu, B., Cyr, R. J., and Palevitz, B. A. (1996). A kinesin-like protein, KatAp, in the cells of arabidopsis and other plants. Plant Cell 8, 119-132.

Liu, C., Qi, X., Zhao, Q., and Yu, J. (2013). Characterization and functional analysis of the potato pollen-specific microtubule-associated protein SBgLR in tobacco. PLoS ONE 8:e60543. doi: 10.1371/journal.pone.0060543

Liu, G., Tang, J. Z., Edmonds, B. T., Murray, J., Levin, S., and Condeelis, J. (1996). F-actin sequesters elongation factor 1 alpha from interaction with aminoacyl-tRNA in a pH-dependent reaction. J. Cell Biol. 135, 953-963.

Lloyd, C., and Hussey, P. (2001). Microtubule-associated proteins in plants why we need a map. Nat. Rev. Mol. Cell Biol. 2, 40-47. doi: 10.1038/350 48005
Mao, G. J., Chan, J., Calder, G., Doonan, J. H., and Lloyd, C. W. (2005). Modulated targeting of GFP-AtMAP65-1 to central spindle microtubules during division. Plant J. 43, 469-478. doi: 10.1111/j.1365-313X.2005.02464.x

Marc, J., Sharkey, D. E., Durso, N. A., Zhang, M., and Cyr, R. J. (1996). Isolation of a 90-kD microtubule-associated protein from tobacco membranes. Plant Cell 8 , 2127-2138. doi: 10.1105/tpc.8.11.2127

Martin, S. W., Glover, B. J., and Davies, J. M. (2005). Lipid microdomains plant membranes get organized. Trends Plant Sci. 10, 263-265. doi: 10.1016/j.tplants.2005.04.004

Mathur, J., Mathur, N., Kernebeck, B., Srinivas, B. P., and Hulskamp, M. (2003). A novel localization pattern for an EB1-like protein links microtubule dynamics to endomembrane organization. Curr. Biol. 13, 1991-1997. doi: 10.1016/j.cub.2003.10.033

Matsui, K., Collings, D., and Asada, T. (2001). Identification of a novel plantspecific kinesin-like protein that is highly expressed in interphase tobacco BY-2 cells. Protoplasma 215, 105-115. doi: 10.1007/BF01280307

Meijer, H. J. G., and Munnik, T. (2003). Phospholipid-based signaling in plants. Аnnu. Rev. Plant Biol. 54, 265-306. doi: 10.1146/annurev.arplant.54.031902.134748

Mineyuki, Y. (1999). The preprophase band of microtubules: its function as a cytokinetic apparatus in higher plants. Int. Rev. Cytol. 187, 1-49. doi: 10.1016/S0074-7696(08)62415-8

Moore, R. C., Durso, N. A., and Cyr, R. J. (1998). Elongation factor-1 alpha stabilizes microtubules in a calcium/calmodulin-dependent manner. Cell Motil. Cytoskeleton 41, 168-180.

Moser, M., Schafer, E., and Ehmann, B. (2000). Characterization of protein and transcript levels of the chaperonin containing tailless complex protein-1 and tubulin during light-regulated growth of oat seedlings. Plant Physiol. 124, 313-320. doi: 10.1104/pp.124.1.313

Muench, D. G., and Park, N.-I. (2006). Messages on the move: the role of the cytoskeleton in mRNA localization and translation in plant cells. Can. J. Bot. 572-580. doi: 10.1139/b05-167

Muller, S., Smertenko, A., Wagner, V., Heinrich, M., Hussey, P. J., and Hauser, M. T. (2004). The plant microtubule-associated protein AtMAP65-3/PLE is essential for cytokinetic phragmoplast function. Curr. Biol. 14, 412-417. doi: 10.1016/j.cub.2004.02.032

Munnik, T. (2001). Phosphatidic acid: an emerging plant lipid second messenger. Trends Plant Sci. 6, 227-233. doi: 10.1016/S1360-1385(01)01918-5

Murray, J. W., Edmonds, B. T., Liu, G., and Condeelis, J. (1996). Bundling of actin filaments by elongation factor 1 alpha inhibits polymerization at filament ends. J. Cell Biol. 135, 1309-1321. doi: 10.1083/jcb.135.5.1309

Nakajima, K., Furutani, I., Tachimoto, H., Matsubara, H., and Hashimoto, T. (2004). SPIRAL1 encodes a plant-specific microtubule-localized protein required for directional control of rapidly expanding Arabidopsis cells. Plant Cell 16, 1178-1190. doi: 10.1105/tpc.017830

Nick, P., Heuing, A., and Ehmann, B. (2000). Plant chaperonins: a role in microtubule-dependent wall formation? Protoplasma 211, 234-244. doi: 10.1007/bf01304491

Oda, Y., Iida, Y., Kondo, Y., and Fukuda, H. (2010). Wood cell-wall structure requires local $2 \mathrm{D}$-microtubule disassembly by a novel plasma membraneanchored protein. Curr. Biol. 20, 1197-1202. doi: 10.1016/j.cub.2010. 05.038

Paredez, A. R., Somerville, C. R., and Ehrhardt, D. W. (2006). Visualization of cellulose synthase demonstrates functional association with microtubules. Science 312, 1491-1495. doi: 10.1126/science.1126551

Parrotta, L., Cresti, M., and Cai, G. (2013). Heat-shock protein 70 binds microtubules and interacts with kinesin in tobacco pollen tubes. Cytoskeleton 70, 522-537. doi: $10.1002 / \mathrm{cm} .21134$

Perez, F., Pernet-Gallay, K., Nizak, C., Goodson, H. V., Kreis, T. E., and Goud, B. (2002). CLIPR-59, a new trans-Golgi/TGN cytoplasmic linker protein belonging to the CLIP-170 family. J. Cell Biol. 156, 631-642. doi: 10.1083/jcb.200111003

Perrin, R. M., Wang, Y., Yuen, C. Y. L., Will, J., and Masson, P. H. (2007). WVD2 is a novel microtubule-associated protein in Arabidopsis thaliana. Plant J. 49, 961-971. doi: 10.1111/j.1365-313X.2006.03015.x

Pesquet, E., Korolev, A. V., Calder, G., and Lloyd, C. W. (2010). The microtubuleassociated protein AtMAP70-5 regulates secondary wall patterning in Arabidopsis wood cells. Curr. Biol. 20, 744-749. doi: 10.1016/j.cub.2010.02.057 
Petrasek, J., Freudenreich, A., Heuing, A., Opatrny, Z., and Nick, P. (1998). Heatshock protein 90 is associated with microtubules in tobacco cells. Protoplasma 202, 161-174. doi: 10.1007/BF01282544

Petrasek, J., and Schwarzerova, K. (2009). Actin and microtubule cytoskeleton interactions. Curr. Opin. Plant Biol. 12, 728-734. doi: 10.1016/j.pbi.2009.09.010

Pleskot, R., Pejchar, P., Staiger, C. J., and Potocky, M. (2014). When fat is not bad: the regulation of actin dynamics by phospholipid signaling molecules. Front. Plant Sci. 5:5. doi: 10.3389/fpls.2014.00005

Pratt, W. B., Krishna, P., and Olsen, L. J. (2001). Hsp90-binding immunophilins in plants: the protein movers. Trends Plant Sci. 6, 54-58. doi: 10.1016/S13601385(00)01843-4

Pratt, W. B., Morishima, Y., Peng, H. M., and Osawa, Y. (2010). Proposal for a role of the Hsp90/Hsp70-based chaperone machinery in making triage decisions when proteins undergo oxidative and toxic damage. Exp. Biol. Med. 235, 278-289. doi: 10.1258/ebm.2009.009250

Pratt, W. B., Silverstein, A. M., and Galigniana, M. D. (1999). A model for the cytoplasmic trafficking of signalling proteins involving the hsp90-binding immunophilins and p50(cdc37). Cell. Signal. 11, 839-851. doi: 10.1016/S08986568(99)00064-9

Preuss, M. L., Kovar, D. R., Lee, Y. R. J., Staiger, C. J., Delmer, D. P., and Liu, B. (2004). A plant-specific kinesin binds to actin microfilaments and interacts with cortical microtubules in cotton fibers. Plant Physiol. 136, 3945-3955. doi: 10.1104/pp.104.052340

Pruyne, D., Gao, L., Bi, E. F., and Bretscher, A. (2004). Stable and dynamic axes of polarity use distinct formin isoforms in budding yeast. Mol. Biol. Cell 15, 4971-4989. doi: 10.1091/mbc.E04-04-0296

Qin, T., Liu, X., Li, J., Sun, J., Song, L., and Mao, T. (2014). Arabidopsis microtubule-destabilizing protein 25 functions in pollen tube growth by severing actin filaments. Plant Cell 26, 325-339. doi: 10.1105/tpc.113.119768

Rosero, A., Zarsky, V., and Cvrckova, F. (2013). AtFH1 formin mutation affects actin filament and microtubule dynamics in Arabidopsis thaliana. J. Exp. Bot. 64, 585-597. doi: 10.1093/jxb/ers351

Ruggenthaler, P., Fichtenbauer, D., Krasensky, J., Jonak, C., and Waigmann, E. (2009). Microtubule-associated protein AtMPB2C plays a role in organization of cortical microtubules, stomata patterning, and tobamovirus infectivity. Plant Physiol. 149, 1354-1365. doi: 10.1104/pp.108.130450

Rutherford, S. L., and Lindquist, S. (1998). Hsp90 as a capacitor for morphological evolution. Nature 396, 336-342. doi: 10.1038/24550

Rutherford, S. L., and Zuker, C. S. (1994). Protein-folding and the regulation of signaling pathways. Cell 79, 1129-1132. doi: 10.1016/0092-8674(94)90003-5

Sagot, I., Klee, S. K., and Pellman, D. (2002). Yeast formins regulate cell polarity by controlling the assembly of actin cables. Nat. Cell Biol. 4, 42-50. doi: $10.1038 /$ ncb719

Sampathkumar, A., Lindeboom, J. J., Debolt, S., Gutierrez, R., Ehrhardt, D. W., Ketelaar, T., et al. (2011). Live cell imaging reveals structural associations between the actin and microtubule cytoskeleton in Arabidopsis. Plant Cell 23, 2302-2313. doi: 10.1105/tpc.111.087940

Sanchez, E. R., Redmond, T., Scherrer, L. C., Bresnick, E. H., Welsh, M. J., and Pratt, W. B. (1988). Evidence that the 90-kilodalton heat-shock protein is associated with tubulin-containing complexes in L-cell cytosol and in intact Ptk cells. Mol. Endocrinol. 2, 756-760. doi: 10.1210/mend-2-8-756

Sano, T., Higaki, T., Oda, Y., Hayashi, T., and Hasezawa, S. (2005). Appearance of actin microfilament 'twin peaks' in mitosis and their function in cell plate formation, as visualized in tobacco BY-2 cells expressing GFP-fimbrin. Plant J. 44, 595-605. doi: 10.1111/j.1365-313X.2005.02558.x

Schneider, R., and Persson, S. (2015). Connecting two arrays: the emerging role of actin-microtubule cross-linking motor proteins. Front. Plant Sci. 6:415. doi: 10.3389/fpls.2015.00415

Sedbrook, J. C. (2004). MAPs in plant cells: delineating microtubule growth dynamics and organization. Curr. Opin. Plant Biol. 7, 632-640. doi: 10.1016/j.pbi.2004.09.017

Sedbrook, J. C., and Kaloriti, D. (2008). Microtubules, MAPs and plant directional cell expansion. Trends Plant Sci. 13, 303-310. doi: 10.1016/j.tplants.2008.04.002

Shiina, N., Gotoh, Y., Kubomura, N., Iwamatsu, A., and Nishida, E. (1994). Microtubule severing by elongation-factor 1-alpha. Science 266, 282-285. doi: 10.1126/science.7939665

Silflow, C. D., Sun, X., Haas, N. A., Foley, J. W., and Lefebvre, P. A. (2011). The Hsp70 and Hsp40 chaperones influence microtubule stability in Chlamydomonas. Genetics 189, 1249-1260. doi: 10.1534/genetics.111. 133587

Sirover, M. A. (1999). New insights into an old protein: the functional diversity of mammalian glyceraldehyde-3-phosphate dehydrogenase. Biochim. Biophys. Acta 1432, 159-184. doi: 10.1016/S0167-4838(99)00119-3

Smertenko, A. P., Chang, H. Y., Wagner, V., Kaloriti, D., Fenyk, S., Sonobe, S., et al. (2004). The Arabidopsis microtubule-associated protein AtMAP651: molecular analysis of its microtubule bundling activity. Plant Cell 16, 2035-2047. doi: 10.1105/tpc.104.023937

Smertenko, A. P., Deeks, M. J., and Hussey, P. J. (2010). Strategies of actin reorganisation in plant cells. J. Cell Sci. 123, 3029-3029. doi: 10.1242/jcs.079749

Smertenko, A. P., Kaloriti, D., Chang, H. Y., Fiserova, J., Opatrny, Z., and Hussey, P. J. (2008). The C-terminal variable region specifies the dynamic properties of arabidopsis microtubule-associated protein MAP65 isotypes. Plant Cell 20, 3346-3358. doi: 10.1105/tpc.108.063362

Smith, L. G., Gerttula, S. M., Han, S. C., and Levy, J. (2001). TANGLED1: a microtubule binding protein required for the spatial control of cytokinesis in maize. J. Cell Biol. 152, 231-236. doi: 10.1083/jcb.152.1.231

Somers, M., Engelborghs, Y., Baert, J. (1990). Analysis of the binding of glyceraldehyde-3-phosphate dehydrogenase to microtubules, the mechanism of bundle formation and the linkage effect. Eur. J. Biochem. 193, 437-444. doi: 10.1111/j.1432-1033.1990.tb19357.x

Suh, B.-C., and Hille, B. (2008). PIP(2) is a necessary cofactor for ion channel function: how and why? Annu. Rev. Biophys. 37, 175-195. doi: 10.1146/annurev.biophys.37.032807.125859

Takabatake, R., Ando, Y., Seo, S., Katou, S., Tsuda, S., Ohashi, Y., et al. (2007) MAP kinases function downstream of HSP90 and upstream of mitochondria in TMV resistance grene N-mediated hypersensitive cell death. Plant Cell Physiol. 48, 498-510. doi: 10.1093/pcp/pcm021

Takahashi, H., Hirota, K., Kawahara, A., Hayakawa, E., and Inoue, Y. (2003). Randomization of cortical microtubules in root epidermal cells induces root hair initiation in lettuce (Lactuca sativa L.) seedlings. Plant Cell Physiol. 44, 350-359. doi: $10.1093 / \mathrm{pcp} / \mathrm{pcg} 043$

Tamura, K., Nakatani, K., Mitsui, H., Ohashi, Y., and Takahashi, H. (1999). Characterization of katD, a kinesin-like protein gene specifically expressed in floral tissues of Arabidopsis thaliana. Gene 230, 23-32. doi: 10.1016/S03781119(99)00070-0

Tapken, W., and Murphy, A. S. (2015). Membrane nanodomains in plants: capturing form, function, and movement. J. Exp. Bot. 66, 1573-1586. doi: 10.1093/jxb/erv054

Terada, S., Kinjo, M., Aihara, M., Takei, Y., and Hirokawa, N. (2010). Kinesin$1 /$ Hsc70-dependent mechanism of slow axonal transport and its relation to fast axonal transport. EMBO J. 29, 843-854. doi: 10.1038/emboj.2009.389

Theologis, A., Ecker, J. R., Palm, C. J., Federspiel, N. A., Kaul, S., White, O., et al. (2000). Sequence and analysis of chromosome 1 of the plant Arabidopsis thaliana. Nature 408, 816-820. doi: 10.1038/35048500

Thomas, C., Tholl, S., Moes, D., Dieterle, M., Papuga, J., Moreau, F., et al. (2009). Actin bundling in plants. Cell Motil. Cytoskeleton 66, 940-957. doi: $10.1002 / \mathrm{cm} .20389$

Tisdale, E. J. (2002). Glyceraldehyde-3-phosphate dehydrogenase is phosphorylated by protein kinase $\mathrm{c}$ mu lambda and plays a role in microtubule dynamics in the early secretory pathway. J. Biol. Chem. 277, 3334-3341. doi: 10.1074/jbc.M109744200

Tisdale, E. J., Azizi, F., and Artalejo, C. R. (2009). Rab2 utilizes glyceraldehyde3-phosphate dehydrogenase and protein kinase $\mathrm{C}$ iota to associate with microtubules and to recruit dynein. J. Biol. Chem. 284, 5876-5884. doi: 10.1074/jbc.M807756200

Traas, J. A., Doonan, J. H., Rawlins, D. J., Shaw, P. J., Watts, J., and Lloyd, C. W. (1987). An actin network is present in the cytoplasm throughout the cell-cycle of carrot cells and associates with the dividing nucleus. J. Cell Biol. 105, 387-395. doi: $10.1083 /$ jcb.105.1.387

Umezu, N., Umeki, N., Mitsui, T., Kondo, K., and Maruta, S. (2011). Characterization of a novel rice kinesin $\mathrm{O} 12$ with a calponin homology domain. J. Biochem. 149, 91-101. doi: 10.1093/jb/mvq122

Van Damme, D., Van Poucke, K., Boutant, E., Ritzenthaler, C., Inze, D., and Geelen, D. (2004). In vivo dynamics and differential microtubule-binding activities of MAP65 proteins. Plant Physiol. 136, 3956-3967. doi: 10.1104/pp.104. 051623 
Volker, K. W., and Knull, H. R. (1997). A glycolytic enzyme binding domain on tubulin. Arch. Biochem. Biophys. 338, 237-243. doi: 10.1006/abbi.1996.9819

Walsh, J. L., Keith, T. J., and Knull, H. R. (1989). Glycolytic enzyme interactions with tubulin and microtubules. Biochim. Biophys. Acta 999, 64-70. doi: 10.1016/0167-4838(89)90031-9

Wang, C. X., and Wang, X. M. (2001). A novel phospholipase D of arabidopsis that is activated by oleic acid and associated with the plasma membrane. Plant Physiol. 127, 1102-1112. doi: 10.1104/pp.010444

Wang, X. M. (2002). Phospholipase D in hormonal and stress signaling. Curr. Opin. Plant Biol. 5, 408-414. doi: 10.1016/S1369-5266(02) 00283-2

Wang, X., Vinocur, B., Shoseyov, O., and Altman, A. (2004). Role of plant heatshock proteins and molecular chaperones in the abiotic stress response. Trends Plant Sci. 9, 244-252. doi: 10.1016/j.tplants.2004.03.006

Wang, X., Zhang, J., Yuan, M., Ehrhardt, D. W., Wang, Z., and Mao, T. (2012). Arabidopsis microtubule destabilizing protein 40 is involved in brassinosteroid regulation of hypocotyl elongation. Plant Cell 24, 5193-5193. doi: $10.1105 /$ tpc. 112.103838

Wang, X., Zhu, L., Liu, B. Q., Wang, C., Jin, L. F., Zhao, Q., et al. (2007). Arabidopsis Microtubule-associated protein 18 functions in directional cell growth by destabilizing cortical microtubules. Plant Cell 19, 877-889. doi: 10.1105/tpc.106.048579

Wegele, H., Muller, L., and Buchner, J. (2004). Hsp70 and Hsp90 - a relay team for protein folding. Rev. Physiol. Biochem. Pharmacol. 151, 1-44. doi: 10.1007/s10254-003-0021-1

Wei, L. Q., Liu, B., and Li, Y. (2005). Distribution of a kinesin-related protein on Golgi apparatus of tobacco pollen tubes. Chinese Sci. Bull. 50, 2175-2181. doi: $10.1007 / \mathrm{bf} 03182668$

Weis, F., Moullintraffort, L., Heichette, C., Chretien, D., and Garnier, C. (2010). The $90-\mathrm{kDa}$ heat shock protein Hsp90 protects tubulin against thermal denaturation. J. Biol. Chem. 285, 9525-9534. doi: 10.1074/jbc.M109. 096586

Welch, M. D., Depace, A. H., Verma, S., Iwamatsu, A., and Mitchison, T. J. (1997). The human Arp2/3 complex is composed of evolutionarily conserved subunits and is localized to cellular regions of dynamic actin filament assembly. J. Cell Biol. 138, 375-384. doi: 10.1083/jcb.138.2.375
Whittington, A. T., Vugrek, O., Wei, K. J., Hasenbein, N. G., Sugimoto, K., Rashbrooke, M. C., et al. (2001). MOR1 is essential for organizing cortical microtubules in plants. Nature 411, 610-613. doi: 10.1038/35079128

Williams, N. E., and Nelsen, E. M. (1997). HSP70 and HSP90 homologs are associated with tubulin in hetero-oligomeric complexes, cilia and the cortex of Tetrahymena. J. Cell Sci. 110, 1665-1672.

Wu, S.-Z., and Bezanilla, M. (2014). Myosin VIII associates with microtubule ends and together with actin plays a role in guiding plant cell division. Elife 3:e03498. doi: 10.7554/eLife.03498

Xu, T., Qu, Z., Yang, X., Qin, X., Xiong, J., Wang, Y., et al. (2009). A cotton kinesin GhKCH2 interacts with both microtubules and microfilaments. Biochem. J. 421, 171-180. doi: 10.1042/BJ20082020

Yanagisawa, M., Zhang, C., and Szymanski, D. B. (2013). ARP2/3-dependent growth in the plant kingdom: SCARs for life. Front. Plant Sci. 4:166. doi: 10.3389/fpls.2013.00166

Yasuhara, H., Muraoka, M., Shogaki, H., Mori, H., and Sonobe, S. (2002). TMBP200, a microtubule bundling polypeptide isolated from telophase tobacco BY-2 cells is a MOR1 homologue. Plant Cell Physiol. 43, 595-603. doi: $10.1093 / \mathrm{pcp} / \mathrm{pcf} 074$

Zeng, C. J. T., Lee, Y. R. J., and Liu, B. (2009). The WD40 repeat protein NEDD1 functions in microtubule organization during cell division in Arabidopsis thaliana. Plant Cell 21, 1129-1140. doi: 10.1105/tpc.109.065953

Zhang, X. P., and Glaser, E. (2002). Interaction of plant mitochondrial and chloroplast signal peptides with the Hsp70 molecular chaperone. Trends Plant Sci. 7, 14-21. doi: 10.1016/S1360-1385(01)02180-X

Conflict of Interest Statement: The authors declare that the research was conducted in the absence of any commercial or financial relationships that could be construed as a potential conflict of interest.

Copyright ( 2016 Krtková, Benáková and Schwarzerová. This is an open-access article distributed under the terms of the Creative Commons Attribution License (CC $B Y$ ). The use, distribution or reproduction in other forums is permitted, provided the original author(s) or licensor are credited and that the original publication in this journal is cited, in accordance with accepted academic practice. No use, distribution or reproduction is permitted which does not comply with these terms. 